\title{
Complete genome sequence of Geobacillus thermoglucosidasius C56-YS93, a novel biomass degrader isolated from obsidian hot spring in Yellowstone National Park
}

\author{
Phillip J. Brumm ${ }^{1,3^{*}}$, Miriam L. Land ${ }^{2}$ and David A. Mead ${ }^{1,3}$
}

\begin{abstract}
Geobacillus thermoglucosidasius C56-YS93 was one of several thermophilic organisms isolated from Obsidian Hot Spring, Yellowstone National Park, Montana, USA under permit from the National Park Service. Comparison of $16 \mathrm{~S}$ rRNA sequences confirmed the classification of the strain as a $G$. thermoglucosidasius species. The genome was sequenced, assembled, and annotated by the DOE Joint Genome Institute and deposited at the NCBI in December 2011 (CP002835). The genome of G. thermoglucosidasius C56-YS93 consists of one circular chromosome of 3,893,306 bp and two circular plasmids of 80,849 and 19,638 bp and an average G + C content of $43.93 \%$. G. thermoglucosidasius C56-YS93 possesses a xylan degradation cluster not found in the other G. thermoglucosidasius sequenced strains. This cluster appears to be related to the xylan degradation cluster found in G. stearothermophilus. G. thermoglucosidasius C56-YS93 possesses two plasmids not found in the other two strains. One plasmid contains a novel gene cluster coding for proteins involved in proline degradation and metabolism, the other contains a collection of mostly hypothetical proteins.
\end{abstract}

Keywords: Geobacillus thermoglucosidasius C56-YS93, Hot springs, Biomass, Xylan, Prophage

\section{Introduction}

Identification of new organisms that produce biomassdegrading enzymes is of considerable interest. Commercial uses for these enzymes include paper manufacturing, brewing, biomass deconstruction and the production of animal feeds [1-3]. Hot springs, especially those at Yellowstone National Park, have been a source of many new organisms including Thermus aquaticus [4, 5], Thermus brockianus [6], and Acidothermus cellulolyticus [7] that possess enzymes with significant potential in biotechnological applications [8]. As part of a project in conjunction with the Great Lakes Bioenergy Research Center, Dept. of Energy, C5-6 Technologies and Lucigen Corp. isolated, characterized, and sequenced a number of

\footnotetext{
* Correspondence: pbrumm@c56technologies.com

'Lucigen Corporation, Middleton, WI, USA

${ }^{3}$ Great Lakes Bioenergy Research Center, University of Wisconsin, Madison, WI, USA

Full list of author information is available at the end of the article
}

new enzyme-producing aerobic organisms from Yellowstone hot springs.

Geobacillus species were the most common aerobic organisms isolated during the cultivation of most hot springs samples. Geobacillus species were originally classified as members of the genus Bacillus, but were reclassified as a separate genus based on 16S rRNA gene sequence analysis, lipid and fatty acid analysis, phenotypic characterization, and DNA-DNA hybridization experiments [9]. Geobacillus species have been isolated from a number of hostile environments including hightemperature oilfields [10], a corroded pipeline in an extremely deep well [11], African [12] and Russian [13] hot springs, marine vents [14], and the Mariana Trench [15], yet they can also be found in garden soils [16] and hay composts [17]. In many cases though, it is unclear if these isolations of Geobacillus species represent vegetative cells growing in these environments or merely spores spread from other locations [18]. The ability of Geobacillus species to thrive in varied and often hostile 
environments suggests that these species possess enzymes suitable for applications in hostile industrial environments. We therefor sequenced a number of these Geobacillus isolates including G. thermoglucosidasius C56-YS93 to identify new enzymes suitable for use in biomass conversion into fuels and chemicals.

\section{Organism Information \\ Classification and Features}

G. thermoglucosidasius C56-YS93 is one of a number of novel thermophilic species isolated from Obsidian Hot Spring, Yellowstone National Park, Montana, USA (44.6100594 $4^{\circ}$ latitude and $-110.4388217^{\circ}$ longitude) under a sampling permit from the National Park Service. The hot spring possesses a $\mathrm{pH}$ of 6.37 and a temperature range of $42-90{ }^{\circ} \mathrm{C}$. The organism was isolated from a sample of hot spring water by enrichment and plating on YTP-2 medium (YTP-2 media contains (per liter) $2.0 \mathrm{~g}$ yeast extract, $2.0 \mathrm{~g}$ tryptone, $2.0 \mathrm{~g}$ sodium pyruvate, $1.0 \mathrm{~g} \mathrm{KCl}, 2.0 \mathrm{~g} \mathrm{KNO}_{3}$, $2.0 \mathrm{~g} \mathrm{Na}_{2} \mathrm{HPO}_{4} .7 \mathrm{H}_{2} \mathrm{O}, 0.1 \mathrm{~g} \mathrm{MgSO}_{4}, 0.03 \mathrm{~g} \mathrm{CaCl}_{2}$, and $2.0 \mathrm{ml}$ clarified tomato juice) at $70{ }^{\circ} \mathrm{C}$. The culture is freely available from the Bacillus Genetic Stock Center (BGSC). Cultures are routinely grown on tryptic soy broth without glucose (TSB) (Difco) media and maintained on TSB agar plates. C5-6 Technologies, Lucigen, the National Park Service, and the Joint Genome Institute have placed no restrictions on the use of the culture or sequence data. $G$. thermoglucosidasius C56-YS93, is a gram-positive, rodshaped facultative anaerobe, (Table 1, Additional file 1: Table S1), with optimum growth temperature of $65^{\circ} \mathrm{C}$ and maximum growth temperature of $75^{\circ} \mathrm{C}$. This is similar to the optimum growth temperature reported for G. thermoglucosidasius TNO-09.020 [19], but significantly higher than reported for previously isolated strains $\left(<60{ }^{\circ} \mathrm{C}\right)$ [9]. G. thermoglucosidasius C56-YS93 appears to grow as a mixture of single cells and large clumps in liquid culture (Fig. 1).

A phylogenetic tree was constructed to identify the relationship of G. thermoglucosidasius C56-YS93 to other members of the Geobacillus family. The phylogeny of $G$. thermoglucosidasius C56-YS93 was determined using its 16S rRNA gene sequence, as well as those of the type strains of all validly described Geobacillus spp. The $16 \mathrm{~S}$ rRNA gene sequences were aligned using MUSCLE [20], pairwise distances were estimated using the Maximum Composite Likelihood (MCL) approach, and initial trees for heuristic search were obtained automatically by applying the Neighbour-Joining method in MEGA 5 [21]. The alignment and heuristic trees were then used to infer the phylogeny using the Maximum Likelihood method based on Tamura-Nei [22]. The phylogenetic tree confirms the identification of G. thermoglucosidasius C56-YS93 as a G. thermoglucosidasius sp. (Fig. 2).
Table 1 Classification and general features of Geobacillus thermoglucosidasius C56-YS93 [48]

\begin{tabular}{|c|c|c|c|}
\hline MIGS ID & Property & Term & $\begin{array}{l}\text { Evidence } \\
\text { code }^{\mathrm{a}}\end{array}$ \\
\hline & \multirow[t]{8}{*}{ Classification } & Domain Bacteria & TAS [49] \\
\hline & & Phylum Firmicutes & TAS [9] \\
\hline & & Class Bacilli & TAS [9] \\
\hline & & Order Bacillales & TAS [9] \\
\hline & & Family Bacillaceae & TAS [9] \\
\hline & & Genus Geobacillus & TAS [9] \\
\hline & & $\begin{array}{l}\text { Species Geobacillus } \\
\text { thermoglucosidasius }\end{array}$ & TAS [9] \\
\hline & & Strain C56-YS93 & \\
\hline & Gram stain & Positive & IDA \\
\hline & Cell shape & Rods and chains of rods & IDA \\
\hline & Motility & Motile & IDA \\
\hline & Sporulation & Subterminal spores & IDA \\
\hline & Temperature range & 55 to $75^{\circ} \mathrm{C}$ & IDA \\
\hline & Optimum temperature & $65^{\circ} \mathrm{C}$ & IDA \\
\hline & pH range; Optimum & $5.8-8.0 ; 7.5$ & IDA \\
\hline & Carbon source & Carbohydrate or protein & IDA \\
\hline GS-6 & Habitat & Hot spring & \\
\hline MIGS-6.3 & Salinity & Not reported & IDA \\
\hline MIGS-22 & Oxygen requirement & Facultative anaerobe & IDA \\
\hline MIGS-15 & Biotic relationship & Free-living & IDA \\
\hline MIGS-14 & Pathogenicity & Non-pathogen & IDA \\
\hline MIGS-4 & Geographic location & $\begin{array}{l}\text { Obsidian Spring, } \\
\text { Yellowstone National } \\
\text { Park, USA }\end{array}$ & IDA \\
\hline MIGS-5 & Sample collection & September 2003 & IDA \\
\hline MIGS-4.1 & Latitude & 44.6603028 & TAS [50] \\
\hline MIGS-4.2 & Longitude & -110.865194 & TAS [50] \\
\hline MIGS-4.4 & Altitude & $2416 m$ & TAS [50] \\
\hline
\end{tabular}

${ }^{a}$ Evidence codes - IDA inferred from direct assay, TAS traceable author statement (i.e., a direct report exists in the literature), NAS non-traceable author statement (i.e., not directly observed for the living, isolated sample, but based on a generally accepted property for the species, or anecdotal evidence). These evidence codes are from http://www.geneontology.org/GO. evidence.shtml of the Gene Ontology project [51]

\section{Genome sequencing information} Genome project history

G. thermoglucosidasius C56-YS93 was selected for sequencing on the basis of its biotechnological potential as part of the U.S. Department of Energy's Genomic Science program (formerly Genomics:GTL). The genome sequence is deposited in the Genomes On Line Database [23, 24] (GOLD ID = Gc01858), and in GenBank (NCBI Reference Sequence $=$ CP002835.1). Sequencing, finishing and annotation were performed by the DOE Joint Genome Institute (JGI). A summary of the project information and its association with MIGS identifiers is shown in Table 2. 


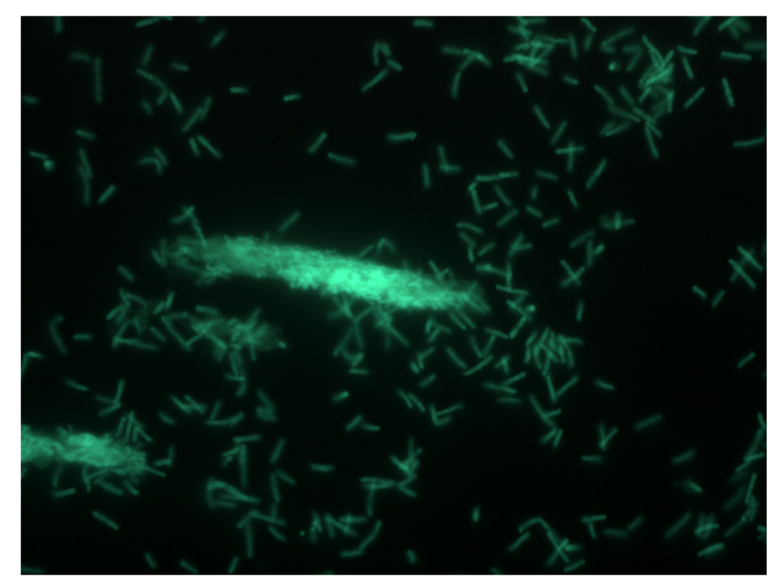

Fig. 1 Micrograph of Geobacillus thermoglucosidasius C56-YS93 cells showing individual cells and clumps of cells. Cells were grown in TSB plus $0.4 \%$ glucose for $18 \mathrm{~h}$. at $70^{\circ} \mathrm{C}$. A $1.0 \mathrm{ml}$ aliquot was removed, centrifuged, re-suspended in $0.2 \mathrm{ml}$ of sterile water, and stained using a $50 \mu \mathrm{M}$ solution of SYTO 9 fluorescent stain in sterile water (Molecular Probes). Dark field fluorescence microscopy was performed using a Nikon Eclipse TE2000-S epifluorescence microscope at 2000x magnification using a high-pressure $\mathrm{Hg}$ light source and a $500 \mathrm{~nm}$ emission filter

\section{Growth conditions and genomic DNA preparation}

For preparation of genomic DNA, 11 cultures of G. thermoglucosidasius C56-YS93 were grown from a single colony in YTP-2 medium at $70{ }^{\circ} \mathrm{C}$ in flasks agitated at $200 \mathrm{rpm}$ and collected by centrifugation. Culture stocks were maintained on YTP-2 agar plates grown at $70{ }^{\circ} \mathrm{C}$. The cell concentrate was lysed using a combination of SDS and proteinase $\mathrm{K}$, and genomic DNA was isolated using a phenol/chloroform extraction [25]. The genomic DNA was precipitated, and treated with RNase to remove residual contaminating RNA.

\section{Genome sequencing and assembly}

The genome of G. thermoglucosidasius C56-YS93 was sequenced at the JGI using a combination of Illumina and 454 technologies [26]. An Illumina GAii shotgun library with reads of $878 \mathrm{Mb}$, a 454 Titanium draft library with average read length of 510-525 bp bases, and a paired end 454 library with average insert size of $13 \mathrm{~Kb}$ were generated for this genome. All general aspects of library construction and sequencing performed at the JGI [27]. Illumina sequencing data was assembled with VELVET [28], and the consensus sequences were shredded into $1.5 \mathrm{~kb}$ overlapped fake reads and assembled together with the 454 data. Draft assemblies were based on 197.18 MB 454 draft data, and all of the 454

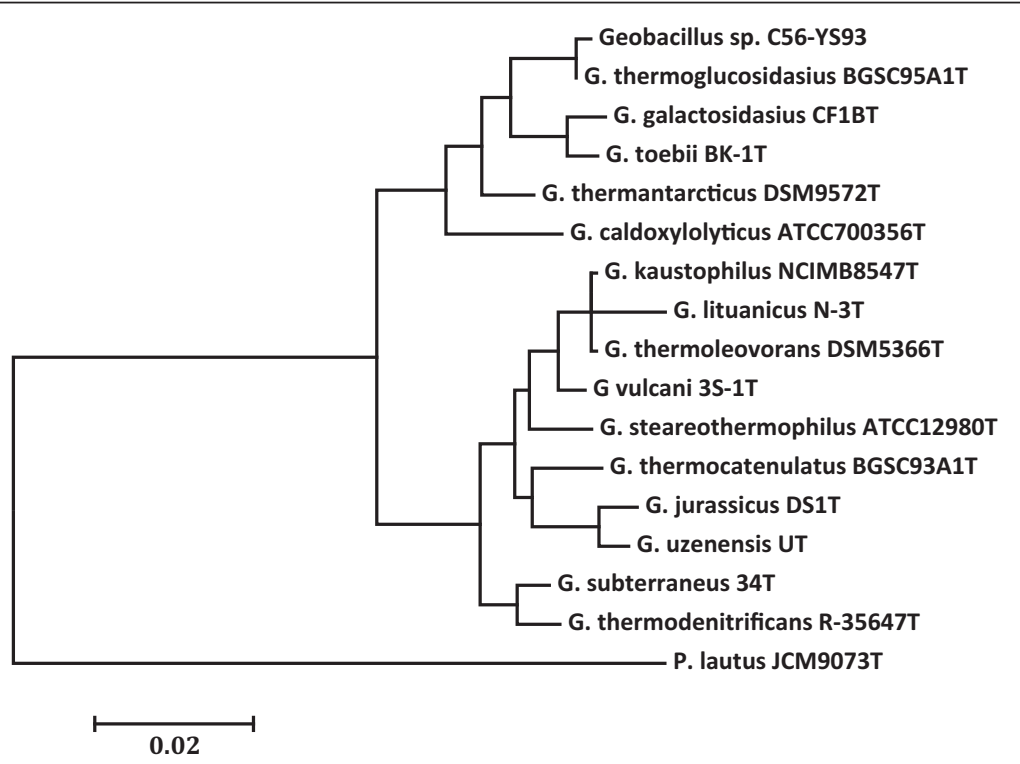

Fig. 2 Molecular phylogenetic analysis by Maximum Likelihood method as detailed in the Material and Methods section. The tree with the highest log likelihood (-3014.19) is shown. The tree is drawn to scale, with branch lengths measured in the number of substitutions per site. The novel sequenced Geobacillus strains are indicated in bold. The type strains of all validly described species are included (NCBI accession numbers): G. caldoxylolyticus ATCC700356 ${ }^{\top}$ (AF067651), G. galactosidasius CF1B ${ }^{\top}$ (AM408559), G. jurassicus DS1 ${ }^{\top}$ (FN428697), G. kaustophilus NCIMB8547T (X60618), G. lituanicus N-3 $3^{\top}$ (AY044055), G. stearothermophilus R-35646 (FN428694), G. subterraneus 34 T (AF276306), G. thermantarcticus DSM9572T(FR749957), G. thermocatenulatus BGSC93A1 ${ }^{\top}$ (AY608935), G. thermodenitrificans R-35647 ${ }^{\top}$ (FN538993), G. thermoglucosidasius BGSC95A1 ${ }^{\top}$ (FN428685), G. thermoleovoransDSM5366 (Z26923), G. toebii BK-1 ${ }^{\top}$ (FN428690), G. uzenensis $U^{\top}$ (AF276304) and G. vulcani 3S-1 ${ }^{\top}$ (AJ293805). The $16 \mathrm{~S}$ rRNA sequence of Paenibacillus lautusJCM9073' (AB073188) was used to root the tree 
Table 2 Project information

\begin{tabular}{lll}
\hline MIGS ID & Property & Term \\
\hline MIGS 31 & Finishing quality & Finished \\
MIGS 28 & Libraries used & 6 and $24 \mathrm{~kb}$ \\
MIGS 29 & Sequencing platforms & 454 Titanium, Illumina GAii \\
MIGS 31.2 & Fold coverage & 5.8 \\
MIGS 30 & Assemblers & Phred/Phrap/Consed \\
MIGS 32 & Gene calling method & Prodigal, GenePRIMP \\
& Locus tag & GEOTH \\
& Genbank ID & CP002835.1 \\
& Genbank date of release & Dec. 1, 2011 \\
& GOLD ID & Gc01858 \\
& BIOPROJECT & PRJNA40781 \\
& Project relevance & Biotechnological \\
MIGS 13 & Source material identifier & Genome \\
&
\end{tabular}

paired end data. Newbler parameters are consed -a 50-1 $350-\mathrm{g}-\mathrm{m}-\mathrm{ml} 20$. The initial Newbler assembly contained 54 contigs in 2 scaffolds. We converted the initial 454 assembly into a phrap assembly by making fake reads from the consensus and collecting the read pairs in the 454 paired end library. The Phred/Phrap/Consed software package was used for sequence assembly and quality assessment ([29-31] in the following finishing process. Illumina data was used to correct potential base errors and increase consensus quality using a software Polisher developed at JGI (Alla Lapidus, unpublished). After the shotgun stage, reads were assembled with parallel phrap (High Performance Software, LLC). Possible mis-assemblies were corrected with gapResolution (Cliff Han, unpublished), Dupfinisher (Han, 2006), or sequencing cloned bridging PCR fragments with subcloning. Gaps between contigs were closed by editing in Consed, by PCR and by Bubble PCR primer walks. A total of 301 additional reactions and 7 shatter libraries were necessary to close gaps and to raise the quality of the finished sequence. The total number of reads used in final assembly was 190,696 . The overall average error rate of the final assembly was 0.02 errors $/ 10 \mathrm{~kb}$.

\section{Genome annotation}

Genes were identified using Prodigal [32] as part of the Oak Ridge National Laboratory genome annotation pipeline, followed by a round of manual curation using the JGI GenePRIMP pipeline [33]. The predicted CDSs were translated and used to search the National Center for Biotechnology Information (NCBI) nonredundant database, UniProt, TIGRFam, Pfam, PRIAM, KEGG, COG, and InterPro databases. These data sources were combined to assert a product description for each predicted protein. Non-coding genes and miscellaneous features were predicted using tRNAscan-SE [33], RNAMMer [34], Rfam [35], TMHMM [36], and signalP [36].

\section{Genome properties}

The genome of G. thermoglucosidasius C56-YS93 consists of one circular chromosome (Table 3 and Fig. 3) of $3,893,306 \mathrm{bp}$ and two circular plasmids of 80,849 and 19,638 bp and an average $\mathrm{G}+\mathrm{C}$ content of $43.93 \%$ (Table 4). There are 90 tRNA genes, 27 rRNA genes and 4 "other" identified RNA genes. There are 4014 predicted protein-coding regions and 255 pseudogenes in the genome. A total of 2757 genes (66.7 \%) have been assigned a predicted function while the rest have been designated as hypothetical proteins (Table 4). The numbers of genes assigned to each COG functional category are listed in Table 5 . About $37 \%$ of the annotated genes were not assigned to a COG or have an unknown function.

\section{Insights from the genome sequence}

To better understand the unique features of G. thermoglucosidasius C56-YS93, whole genome comparisons were carried out between G. thermoglucosidasius C56YS93 and G. thermoglucosidasius M10EXG (M10EXG) and G. thermoglucosidasius TNO-09.020 (TNO-09.020) (accession number: NZ_CM001483.1) using RAST genome annotation [37] and SEED curation into subsystems [38]. (The genome sequence of M10EXG is available from the Integrated Microbial Genomes (IMG) database $[27,39]$.) Basic features of the three genomes are shown in Table 6. Genome comparisons revealed that C56YS93 possessed a number of unique features.

\section{Xylan degradation cluster in G. thermoglucosidasius C56-YS93}

The most significant unique feature of G. thermoglucosidasius C56-YS93 is a 26-gene cluster coding for xylan utilization not found in any G. thermoglucosidasius genome. Included in the cluster are regulatory elements, transporters, intracellular and extracellular xylanases, and enzymes involved in xylose metabolism (Table 7). Manual curation of the cluster indicates that the genes and organization of the G. thermoglucosidasius C56YS93 xylan utilization cluster are essentially identical to

Table 3 Summary of genome: one chromosome and two plasmids

\begin{tabular}{lclll}
\hline Label & Size (Mb) & Topology & INSDC identifier & RefSeq ID \\
\hline Chromosome & 3.65 & Circular & CP002050.1 & NC_14206.1 \\
Plasmid 1 & 0.081 & Circular & CP002836.1 & NC_015665 \\
Plasmid 2 & 0.020 & Circular & CP002837.1 & NC_015661 \\
\hline
\end{tabular}




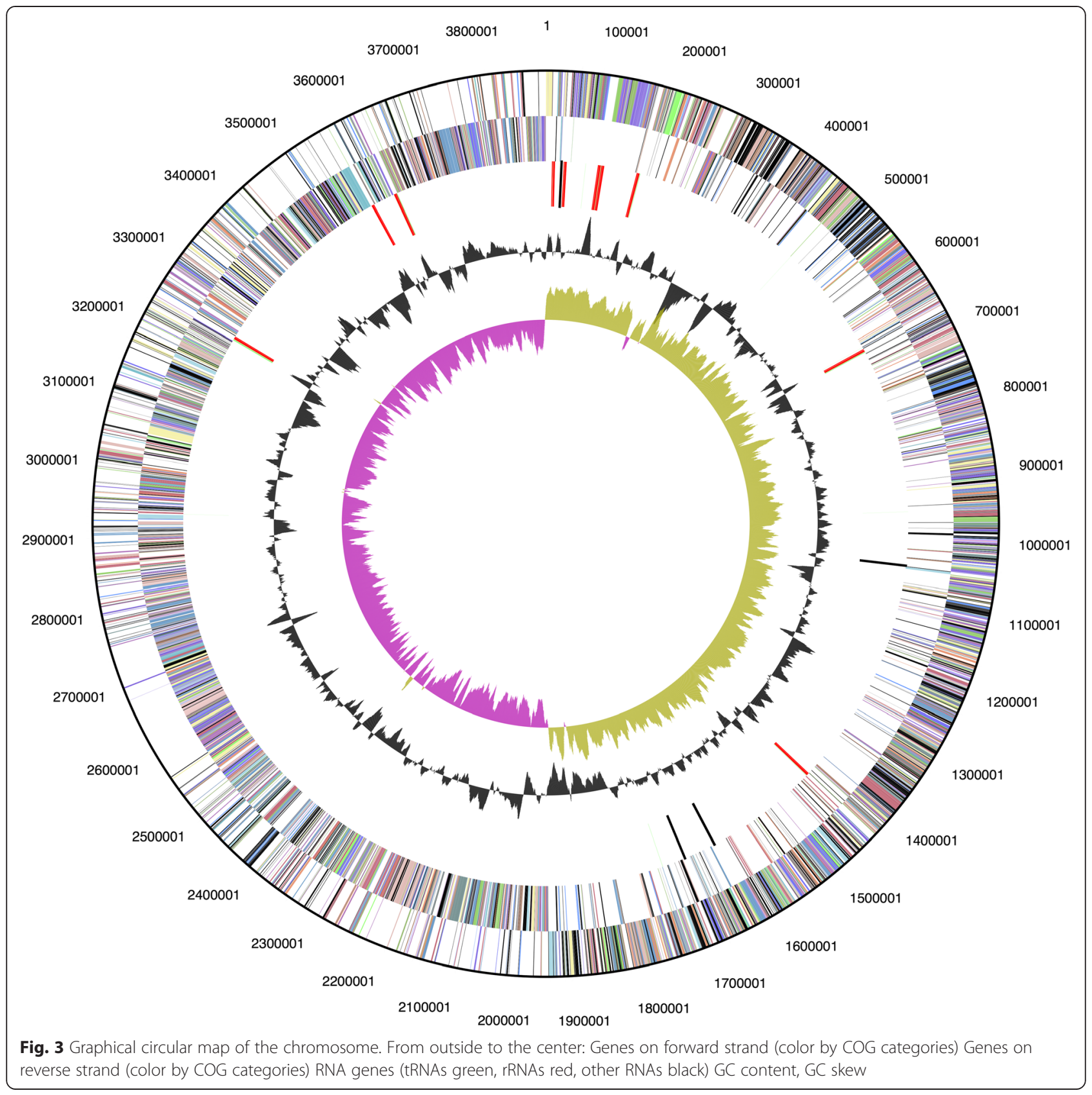

those of the G. stearothermophilus cluster (Bst T-6) [40]. This identity suggests the cluster may be highly conserved within the xylanolytic geobacilli. No homologs of the corresponding G. stearothermophilus arabinan utilization [41] cluster genes are present in G. thermoglucosidasius C56-YS93, indicating G. thermoglucosidasius C56-YS93 is unable to utilize arabinan.

\section{Nitrogen clusters in G. thermoglucosidasius C56-YS93}

G. thermoglucosidasius C56-YS93 has a number of nitrogen utilization systems. The absence of an arabinan cluster in G. thermoglucosidasius C56-YS93 is the result of an 11-gene insert (Geoth_2276 through Geoth_2288) coding for a peptide utilization cluster that replaces part of the arabinan cluster. The cluster does not code for a secreted protease or peptidase, but contains an annotated five-gene $\mathrm{ABC}$ peptide transporter system and two intracellular peptidases. Downstream from the peptide utilization cluster is a 12-gene urea uptake and utilization cluster (Geoth_2301 through Geoth_2312). The organism contains clusters for reduction of nitrate to nitrite (Geoth_2197 through Geoth_2200) and reduction of nitrite to dintrogen (Geoth_3084 through Geoth_3090). 
Table 4 Genome statistics

\begin{tabular}{lrr}
\hline Attribute & \multicolumn{1}{l}{ Value } & \% of Total \\
\hline Genome size (bp) & $3,993,793$ & 100 \\
DNA coding (bp) & $3,437,131$ & 86 \\
DNA G+C (bp) & $1,754,637$ & 44 \\
DNA Scaffolds & 3 & 100 \\
Total genes & 4,135 & 100 \\
Protein-coding genes & 4,014 & 97 \\
RNA genes & 121 & 3 \\
Pseudo genes & 255 & 6 \\
Genes in internal clusters & 1,984 & 48 \\
Genes with function prediction & 1,257 & 30 \\
Genes assigned to COGs & 2,607 & 63 \\
Genes with Pfam domains & 3,278 & 79 \\
Genes with signal peptides & 161 & 4 \\
Genes with transmembrane helices & 948 & 23 \\
CRISPR repeats & 6 & \\
\hline
\end{tabular}

${ }^{a}$ The total is based on either the size of the genome in base pairs or the total number of protein coding genes in the annotated genome

Presence of plasmids in G. thermoglucosidasius C56-YS93 While the genomes of strains TNO-09.020 and M10EXG contain no plasmids, the genome of G. thermoglucosidasius C56-YS93 includes two plasmids, one of approximately 81 $\mathrm{Kb}$ and one of approximately $20 \mathrm{~Kb}$. The $20 \mathrm{~Kb}$ plasmid contains genes coding for a number of small hypothetical proteins with no identifiable function. Among the annotated proteins, the $20 \mathrm{~Kb}$ plasmid contains an annotated $\mathrm{P} 4$ phage/plasmid primase with no close homologs in other Geobacillus strains (Geoth_0020) and an annotated ArpU family phage transcriptional regulator (Geoth_0016). The $20 \mathrm{~Kb}$ plasmid contains an annotated transcriptional modulator of MazE/toxin, MazF (Geoth_0007) that may function in maintaining the plasmid. The $80 \mathrm{~Kb}$ plasmid contains a gene cluster that may function for proline and hydroxyproline capture, transport and metabolism. The cluster includes two peptidases (Geoth_3970 and Geoth_3979), a transport system and hydroxyglutarate oxidase cluster (Geoth_4004 and Geoth_3999), four annotated oxoprolinases (Geoth_3972, Geoth_3973, Geoth_3984, and Geoth_3987), and a hydantoin racemase (Geoth_3976) The plasmid also contains genes coding for proteins that metabolize proline to glutamate via proline dehydrogenase. (Geoth_3968 and Geoth_3969). BLAST analysis indicates that these two proteins are not common to Geobacillus species, but appear to have been acquired from an Anoxybacillus species. In addition, the $80 \mathrm{~kb}$ plasmid contains genes coding for eight proteins annotated as integrase or transposon-related and annotated death-on-curing and addiction module antidote proteins (Geoth_4023 and Geoth_4024) that may function in maintaining the plasmid.
Table 5 Number of genes associated with general COG functional categories

\begin{tabular}{|c|c|c|c|}
\hline Code & Value & Percent & Description \\
\hline J & 156 & 5.4 & Translation, ribosomal structure and biogenesis \\
\hline A & 0 & 0 & RNA processing and modification \\
\hline K & 195 & 6.8 & Transcription \\
\hline L & 208 & 7.2 & Replication, recombination and repair \\
\hline B & 1 & 0.03 & Chromatin structure and dynamics \\
\hline D & 30 & 1.0 & $\begin{array}{l}\text { Cell cycle control, cell division, chromosome } \\
\text { partitioning }\end{array}$ \\
\hline V & 44 & 1.5 & Defense mechanisms \\
\hline T & 116 & 4.0 & Signal transduction mechanisms \\
\hline M & 103 & 3.6 & Cell wall/membrane/envelope biogenesis \\
\hline N & 61 & 2.1 & Cell motility \\
\hline U & 48 & 1.7 & $\begin{array}{l}\text { Intracellular trafficking, secretion, and vesicular } \\
\text { transport }\end{array}$ \\
\hline O & 100 & 3.5 & $\begin{array}{l}\text { Posttranslational modification, protein turnover, } \\
\text { chaperones }\end{array}$ \\
\hline C & 207 & 7.2 & Energy production and conversion \\
\hline G & 194 & 6.7 & Carbohydrate transport and metabolism \\
\hline E & 285 & 9.9 & Amino acid transport and metabolism \\
\hline $\mathrm{F}$ & 72 & 2.5 & Nucleotide transport and metabolism \\
\hline $\mathrm{H}$ & 132 & 4.6 & Coenzyme transport and metabolism \\
\hline । & 105 & 3.6 & Lipid transport and metabolism \\
\hline P & 160 & 5.6 & Inorganic ion transport and metabolism \\
\hline Q & 71 & 2.5 & $\begin{array}{l}\text { Secondary metabolites biosynthesis, transport } \\
\text { and catabolism }\end{array}$ \\
\hline $\mathrm{R}$ & 330 & 11.5 & General function prediction only \\
\hline \multirow[t]{2}{*}{ S } & 261 & 9.1 & Function unknown \\
\hline & 1528 & 37.0 & Not in COGs \\
\hline
\end{tabular}

The total is based on the total number of protein coding genes in the annotated genome

Prophage insert in G. thermoglucosidasius C56-YS93

Prophage analysis of the G. thermoglucosidasius C56-YS93 genome was performed using PHAST genome search software [42]. PHAST identified a $56 \mathrm{~KB}$ insert containing an intact prophage between 735,196 and $780,775 \mathrm{bp}$. The insert contains 75 genes, of which 51 are annotated as having a phage origin, 20 are annotated as hypothetical proteins and four are annotated as bacterial (Fig. 4).

Table 6 G. thermoglucosidasius strains used in comparisons

\begin{tabular}{llll}
\hline G. thermoglucosidasius & C56-YS93 & M10EXG & TNO-09.020 \\
\hline Chromosome size & $3,993,793$ & $3,773,252$ & $3,740,238$ \\
Plasmids & 2 & 0 & 0 \\
Protein coding genes & 4326 & 4228 & 4164 \\
Isolation source & $\begin{array}{l}\text { Hot Spring, } \\
\text { YNP, United } \\
\text { States }\end{array}$ & $\begin{array}{l}\text { Sydney, New } \\
\text { South Wales, } \\
\text { Australia }\end{array}$ & $\begin{array}{l}\text { Dairy } \\
\text { production, } \\
\text { Netherlands }\end{array}$ \\
\hline
\end{tabular}


Table 7 Xylan degradation cluster of Geobacillus thermoglucosidasius C56-YS93

\begin{tabular}{|c|c|c|c|}
\hline & Annotated protein function & C56-YS93 & Bst T-6 \\
\hline 1 & $\begin{array}{l}\text { Integral membrane sensor signal } \\
\text { transduction histidine kinase }\end{array}$ & Geoth_2272 & xynD \\
\hline 2 & AraC family transcriptional regulator & Geoth_2271 & xynC \\
\hline 3 & $\begin{array}{l}\text { Family } 1 \text { extracellular solute-binding } \\
\text { protein }\end{array}$ & Geoth_2270 & xynE \\
\hline 4 & $\begin{array}{l}\text { Binding-protein-dependent transporters } \\
\text { inner membrane component }\end{array}$ & Geoth_2269 & xynF \\
\hline 5 & $\begin{array}{l}\text { Binding-protein-dependent transporters } \\
\text { inner membrane component }\end{array}$ & Geoth_2268 & xynG \\
\hline 6 & Aldose 1-epimerase & Geoth_2267 & arak \\
\hline 7 & Polysaccharide deacetylase & Geoth_2266 & axe1 \\
\hline 8 & Xylan 1,4-beta-xylosidase & Geoth_2265 & xynB2 \\
\hline 9 & Endo-1,4-beta-xylanase & Geoth_2264 & xynA2 \\
\hline 10 & $\begin{array}{l}\text { Family } 1 \text { extracellular solute-binding } \\
\text { protein }\end{array}$ & Geoth_2262 & aguE \\
\hline 11 & $\begin{array}{l}\text { Binding-protein-dependent transporters } \\
\text { inner membrane component }\end{array}$ & Geoth_2261 & aguF \\
\hline 12 & $\begin{array}{l}\text { Binding-protein-dependent transporters } \\
\text { inner membrane component }\end{array}$ & Geoth_2260 & aguG \\
\hline 13 & Alpha-glucuronidase & Geoth_2259 & aguA \\
\hline 14 & Xylan 1,4-beta-xylosidase & Geoth_2258 & xynB \\
\hline 15 & PfkB domain-containing protein & Geoth_2257 & kdgK \\
\hline 16 & $\begin{array}{l}\text { 2-dehydro-3-deoxyphosphogluconate } \\
\text { aldolase/4-hydroxy-2-oxoglutarate aldolase }\end{array}$ & Geoth_2256 & $\mathrm{kgdA}$ \\
\hline 17 & GntR family transcriptional regulator & Geoth_2255 & uxuR \\
\hline 18 & Uronate isomerase & Geoth_2254 & uxaC \\
\hline 19 & Mannonate dehydratase & Geoth_2253 & uxuA \\
\hline 20 & Short-chain dehydrogenase/reductase SDR & Geoth_2252 & uxuB \\
\hline 21 & Hypothetical protein & Geoth_2251 & orfa \\
\hline 22 & Endo-1,4-beta-xylanase & Geoth_2250 & xynA1 \\
\hline 23 & Hypothetical protein & Geoth_2247 & xynX \\
\hline 24 & G-D-S-L family lipolytic protein & Geoth_2246 & axe2 \\
\hline 25 & Xylose isomerase & Geoth_2243 & xylA \\
\hline 26 & Xylulokinase & Geoth_2242 & xylB \\
\hline
\end{tabular}

BLAST analysis indicates the phage proteins in the insert most closely match those of Geobacillus virus E2 (Accession: NC_009552.2) with 26 protein hits.

\section{Conclusions}

G. thermoglucosidasius species were first isolated by Suzuki and given the name Bacillus thermoglucosidasius [43]. The organisms were reclassified as Geobacillus and their name corrected to thermoglucosidasius [9]. G. thermoglucosidasius C56-YS93 is the first G. thermoglucosidasius strain from a hot spring environment for which a whole genome sequence is available. While it is possible that $G$. thermoglucosidasius C56-YS93 was present only as wind- blown spores in the hot spring [18], there are a number of strong arguments for the growth of this and other Geobacillus species in hot springs. The first and most compelling argument is that, in our lab, boiled samples of Obsidian hot spring water resulted in isolation of no viable organisms, either in liquid culture or by plating. If Geobacillus spores were present in a significant quantity, a significant number of isolates would be expected. Secondly, we have been able to isolate Geobacillus species only from alkaline or neutral hot springs with temperatures between 60 and $80{ }^{\circ} \mathrm{C}$, essentially the environment in which Geobacillus species can grow. No Geobacillus species were isolated from acidic hot springs located close to the alkaline and neutral springs. The isolation of wind-borne spore cultures would predict equal numbers of Geobacillus species isolated from acidic and alkaline springs. Thirdly, in our work, Geobacillus species and Thermus species were the predominant organisms isolated from Yellowstone hot springs under aerobic conditions. Thermus species share temperature and $\mathrm{pH}$ optima with Geobacillus species. Thermus species do not sporulate, so the presence of Thermus species cannot be attributed to wind-blown spores, but indicates the organism is growing in the hot spring. If these hot springs support growth of Thermus species, it would be difficult to argue that the hot springs can support growth of Thermus species but cannot support growth of with Geobacillus species. Finally, Geobacillus species have been isolated from microbial mats from other hot springs in Yellowstone [44].

G. thermoglucosidasius, C56-YS93, appears to have a number of unique features as a result of its growth in the hot spring environment. The organism possesses a large xylan degradation cluster that increases the substrate range of this strain relative to the other two sequenced strains. A number of other biomass-degrading organisms have been identified in Obsidian Hot Spring [45], but this is the first reported biomass-degrading Geobacillus species from the hot spring. The organization of this cluster appears to match the glucuronic acid utilization cluster described for G. stearothermophilus [40], suggesting this cluster may be conserved in other Geobacillus species. G. thermoglucosidasius C56-YS93 possesses both chromosomal and plasmid-borne peptide utilization clusters that may allow the organism to scavenge proteins and peptides from the medium. G. thermoglucosidasius C56-YS93 also possesses the ability to reduce nitrate to dinitrogen, possibly utilizing nitrate as an alternate electron acceptor in the oxygen-poor high temperature environment. Genetic exchange with other Geobacillus species in the hot spring may be facilitated by the presence of the two plasmids not found in the other two strains. Further work is needed to identify the function of the genes present on these two plasmids and clarify the role they play in survival in the hot 

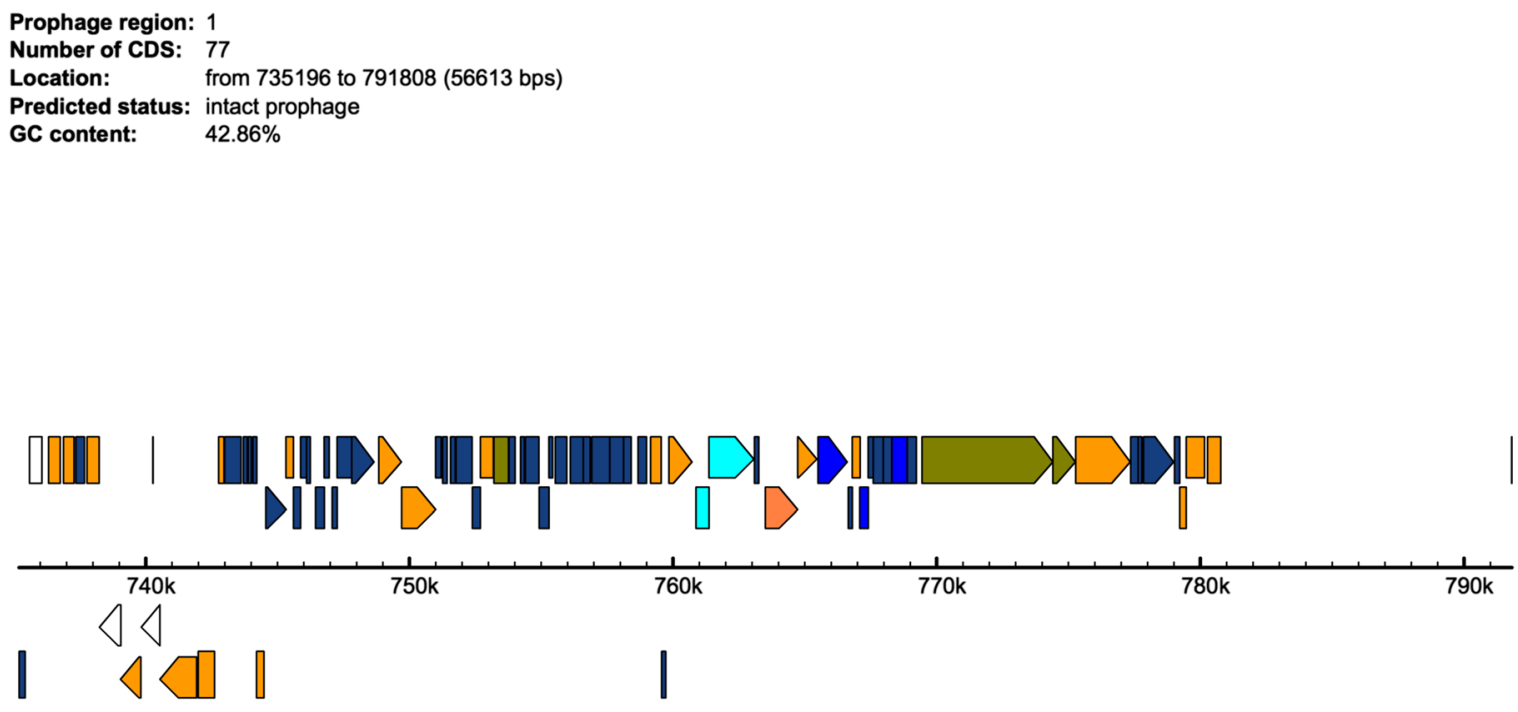

Identified CDS types:

\begin{tabular}{|c|c|c|c|c|c|}
\hline 1 & Lysis & 2 & Terminase & 3 & Portal \\
\hline 4 & Protease & 5 & Coat & 6 & Tail shaft \\
\hline 7 & Attachment site & 8 & Intergrase & 9 & Other phage-like protein \\
\hline 10 & Hypothetical protein & 11 & Other & 12 & Transposase \\
\hline 13 & Tail fiber & 14 & Plate & 15 & tRNA \\
\hline
\end{tabular}

Fig. 4 Prophage genes identified in G. thermoglucosidasius C56-YS93 using PHAST genome search software

spring. Metagenomic analysis of samples from two other hot springs in Yellowstone National Park, Bear Paw and Octopus, shows the presence of active archaeal and bacterial phage populations [46, 47]. The prophage identified in G. thermoglucosidasius C56-YS93 (43.9 \% G + C) is unrelated to the prophages identified in Geobacillus species Y412MC52 and Y412MC61 (52.3 \% G + C), isolated from the same hot spring. This suggests that the identified prophage identified in G. thermoglucosidasius C56-YS93 may be specific to G. thermoglucosidasius, or to the lower $\mathrm{G}+\mathrm{C}$ species. Additional work is needed to understand the relationship between Geobacillus species and the phages that infect them.

\section{Additional file}

Additional file 1: Table S1. Associated MIGS record.
Competing interests

The authors declare that they have no competing interests.

\section{Authors' contributions}

PJB isolated and characterized the organism and wrote the manuscript, DAM managed the hot spring sampling, DNA preparation and submission to JGl for sequencing, and MLL did the genome annotation and document editing. All authors read and approved the final manuscript.

\section{Acknowledgements}

This work was funded by the DOE Great Lakes Bioenergy Research Center (DOE Office of Science BER DE-FC02-07ER64494). Sequencing work was performed under the auspices of the US Department of Energy's Office of Science, Biological and Environmental Research Program, and by the University of California, Lawrence Berkeley National Laboratory under contract No. DE-AC02-05CH11231, Lawrence Livermore National Laboratory under Contract No. DE-AC52-07NA27344, and Los Alamos National Laboratory under contract No. DE-AC02-06NA25396.

\section{Author details}

${ }^{1}$ Lucigen Corporation, Middleton, WI, USA. ${ }^{2}$ Oak Ridge National Laboratory, Oak Ridge, TN, USA. ${ }^{3}$ Great Lakes Bioenergy Research Center, University of Wisconsin, Madison, WI, USA.

Received: 8 September 2014 Accepted: 29 June 2015

Published online: 05 October 2015 


\section{References}

1. Valls C, Gallardo O, Vidal T, Pastor Fl, Diaz P, Roncero MB. New xylanases to obtain modified eucalypt fibres with high-cellulose content. Bioresour Technol. 2010;101(19):7439-45. doi:10.1016/j.biortech.2010.04.085. PubMed. Epub 2010/10/13.

2. Valls C, Roncero MB. Using both xylanase and laccase enzymes for pulp bleaching. Bioresour Technol. 2009;100(6):2032-9. doi:10.1016/ j.biortech.2008.10.009. PubMed. Epub 2008/11/29.

3. Tricarico JM, Dawson KA. Influence of supplemental endoglucanase or xylanase on volatile fatty acid production from ruminant feed by ruminal in vitro cultures. Arch Anim Nutr. 2005;59(5):325-34. doi:10.1080/ 17450390500247865. PubMed. Epub 2005/12/03.

4. Brock TD, Freeze $H$. Thermus aquaticus gen. n. and sp. n., a nonsporulating extreme thermophile. J Bacteriol. 1969;98(1):289-97. Epub 1969/04/01. PubMed PMID: 5781580; PubMed Central PMCID: PMC249935.

5. Brock TD, Edwards MR. Fine structure of Thermus aquaticus, an extreme thermophile. J Bacteriol. 1970;104(1):509-17. PubMed PMID: 5473907; PubMed Central PMCID: PMC248237.

6. Williams RA, Smith KE, Welch SG, Micallef J, Sharp RJ. DNA relatedness of Thermus strains, description of Thermus brockianus sp. nov., and proposal to reestablish Thermus thermophilus (Oshima and Imahori). Int I Syst Bacteriol. 1995;45(3):495-9. Epub 1995/07/01. PubMed.

7. Mohagheghi A, Grohmann K, Himmel M, Leighton L, Updegraff DM. Isolation and characterization of Acidothermus cellulolyticus gen. nov., sp. nov., a new genus of thermophilic, acidophilic, cellulolytic bacteria. Int J Syst Bacteriol. 1986;36:435-43.

8. Brock TD. The value of basic research: discovery of Thermus aquaticus and other extreme thermophiles. Genetics. 1997;146(4):1207-10. PubMed PMID: 9258667; PubMed Central PMCID: PMC1208068.

9. Nazina TN, Tourova TP, Poltaraus AB, Novikova EV, Grigoryan AA, Ivanova $A E$, et al. Taxonomic study of aerobic thermophilic bacilli: descriptions of Geobacillus subterraneus gen. nov., sp. nov. and Geobacillus uzenensis sp. nov. from petroleum reservoirs and transfer of Bacillus stearothermophilus, Bacillus thermocatenulatus, Bacillus thermoleovorans, Bacillus kaustophilus, Bacillus thermodenitrificans to Geobacillus as the new combinations $G$. stearothermophilus, G. thermocatenulatus, G. thermoleovorans, G. kaustophilus, G. thermoglucosidasius and G. thermodenitrificans. Int I Syst Evol Microbiol. 2001;51(Pt 2):433-46. Epub 2001/04/26. PubMed.

10. Kuisiene N, Raugalas J, Chitavichius D. Geobacillus lituanicus sp. nov. Int J Syst Evol Microbiol. 2004;54(Pt 6):1991-5. doi:10.1099/ijs.0.02976-0. PubMed. Epub 2004/11/17.

11. Popova NA, Nikolaev lu A, Turova TP, Lysenko AM, Osipov GA, Verkhovtseva NV, et al. Geobacillus uralicus, a new species of thermophilic bacteria. Mikrobiologiia. 2002;71(3):391-8. Epub 2002/07/26. PubMed.

12. Hawumba JF, Theron J, Brozel VS. Thermophilic protease-producing Geobacillus from Buranga hot springs in Western Uganda. Curr Microbiol. 2002;45(2):144-50. doi:10.1007/s00284-001-0116-3. Epub 2002/06/19. PubMed.

13. Nazina TN, Lebedeva EV, Poltaraus AB, Tourova TP, Grigoryan AA, Sokolova D, et al. Geobacillus gargensis sp. nov., a novel thermophile from a hot spring, and the reclassification of Bacillus vulcani as Geobacillus vulcani comb. nov. Int J Syst Evol Microbiol. 2004;54(Pt 6):2019-24. doi:10.1099/ ijs.0.02932-0. Epub 2004/11/17. PubMed.

14. Maugeri TL, Gugliandolo C, Caccamo D, Stackebrandt E. Three novel halotolerant and thermophilic Geobacillus strains from shallow marine vents. Syst Appl Microbiol. 2002;25(3):450-5. doi:10.1078/0723-2020-00119. Epub 2002/11/08. PubMed.

15. Takami H, Nishi S, Lu J, Shimamura S, Takaki Y. Genomic characterization of thermophilic Geobacillus species isolated from the deepest sea mud of the Mariana Trench. Extremophiles. 2004;8(5):351-6. doi:10.1007/s00792-004-0394-3. Epub 2004/05/29. PubMed.

16. Wiegand S, Rabausch U, Chow J, Daniel R, Streit WR, Liesegang H. Complete genome sequence of Geobacillus sp. Strain GHH01, a thermophilic lipase-secreting bacterium. Genome Announc. 2013;1(2):e0009213. doi:10.1128/genomeA.00092-13. Epub 2013/04/27. PubMed PMID: 23618712; PubMed Central PMCID: PMC3636540.

17. Sung MH, Kim H, Bae JW, Rhee SK, Jeon CO, Kim K, et al. Geobacillus toebii sp. nov., a novel thermophilic bacterium isolated from hay compost. Int J Syst Evol Microbiol. 2002;52(Pt 6):2251-5. Epub 2003/01/02. PubMed.

18. Zeigler DR. The Geobacillus paradox: why is a thermophilic bacterial genus so prevalent on a mesophilic planet? Microbiology. 2013. Epub 2013/10/03 doi:10.1099/mic.0.071696-0. PubMed.
19. Zhao Y, Caspers MP, Abee T, Siezen RJ, Kort R. Complete genome sequence of Geobacillus thermoglucosidans TNO-09.020, a thermophilic sporeformer associated with a dairy-processing environment. J Bacteriol. 2012;194(15):4118. doi:10.1128/JB.00318-12. Epub 2012/07/21. PubMed PMID: 22815439; PubMed Central PMCID: PMC3416512.

20. Edgar RC. MUSCLE: multiple sequence alignment with high accuracy and high throughput. Nucleic Acids Res. 2004;32(5):1792-7. doi:10.1093/nar/ gkh340. Epub 2004/03/23. PubMed PMID: 15034147; PubMed Central PMCID: PMCPmc390337.

21. Tamura K, Peterson D, Peterson N, Stecher G, Nei M, Kumar S. MEGA5: molecular evolutionary genetics analysis using maximum likelihood, evolutionary distance, and maximum parsimony methods. Mol Biol Evol. 2011;28(10):2731-9. doi:10.1093/molbev/msr121. Epub 2011/05/07. PubMed PMID: 21546353; PubMed Central PMCID: PMC3203626.

22. Tamura K, Nei M. Estimation of the number of nucleotide substitutions in the control region of mitochondrial DNA in humans and chimpanzees. Mol Biol Evol. 1993;10(3):512-26. Epub 1993/05/01. PubMed.

23. Liolios K, Tavernarakis N, Hugenholtz P, Kyrpides NC. The Genomes On Line Database (GOLD) v. 2: a monitor of genome projects worldwide. Nucleic Acids Res. 2006;34(Database issue):D332-4. doi:10.1093/nar/gkj145. PubMed PMID: 16381880; PubMed Central PMCID: PMC1347507.

24. Liolios K, Chen IM, Mavromatis K, Tavernarakis N, Hugenholtz P, Markowitz VM, et al. The Genomes On Line Database (GOLD) in 2009: status of genomic and metagenomic projects and their associated metadata. Nucleic Acids Res. 2010;38(Database issue):D346-54. doi:10.1093/nar/gkp848. PubMed PMID: 19914934; PubMed Central PMCID: PMC2808860.

25. Sambrook J, Fritsch EF, Maniatis T. Molecular cloning: a laboratory manual. NY: Cold Spring Harbor Laboratory Press; 1989.

26. Margulies M, Egholm M, Altman WE, Attiya S, Bader JS, Bemben LA, et al Genome sequencing in microfabricated high-density picolitre reactors. Nature. 2005;437(7057):376-80. doi:10.1038/nature03959. Epub 2005/08/02. PubMed PMID: 16056220; PubMed Central PMCID: PMCPmc1464427.

27. Markowitz VM, Korzeniewski F, Palaniappan K, Szeto E, Werner G, Padki A, et al. The Integrated Microbial Genomes (IMG) system. Nucleic Acids Res. 2006;34(Database issue):D344-8. doi:10.1093/nar/gkj024. Epub 2005/ 12/31. PubMed PMID: 16381883; PubMed Central PMCID: PMCPmc1347387.

28. Zerbino DR. Using the Velvet de novo assembler for short-read sequencing technologies. Curr Protoc Bioinformatics. 2010;Chapter 11:Unit 11.5. doi:10.1002/0471250953.bi1105s31. Epub 2010/09/14. PubMed PMID: 20836074; PubMed Central PMCID: PMCPmc2952100.

29. Ewing B, Hillier L, Wendl MC, Green P. Base-calling of automated sequencer traces using phred. I. Accuracy assessment. Genome Res. 1998;8(3):175-85. PubMed.

30. Ewing B, Green P. Base-calling of automated sequencer traces using phred II. Error probabilities. Genome Res. 1998;8(3):186-94. PubMed.

31. Gordon D, Abajian C, Green P. Consed: a graphical tool for sequence finishing. Genome Res. 1998;8(3):195-202. PubMed.

32. Hyatt D, Chen GL, Locascio PF, Land ML, Larimer FW, Hauser L. Prodigal prokaryotic dynamic programming genefinding algorithm. BMC Bioinformatics. 2010;11:119.

33. Lowe TM, Eddy SR. tRNAscan-SE: a program for improved detection of transfer RNA genes in genomic sequence. Nucleic Acids Res. 1997;25(5):955-64. Epub 1997/03/01. PubMed PMID: 9023104; PubMed Central PMCID: PMC146525.

34. Lagesen K, Hallin P, Rodland EA, Staerfeldt HH, Rognes T, Ussery DW. RNAmmer: consistent and rapid annotation of ribosomal RNA genes. Nucleic Acids Res. 2007;35(9):3100-8. doi:10.1093/nar/gkm160. Epub 2007/04/25. PubMed PMID: 17452365; PubMed Central PMCID: PMC1888812.

35. Griffiths-Jones S, Bateman A, Marshall M, Khanna A, Eddy SR. Rfam: an RNA family database. Nucleic Acids Res. 2003;31(1):439-41. Epub 2003/01/10. PubMed PMID: 12520045; PubMed Central PMCID: PMC165453.

36. Krogh A, Larsson B, von Heijne G, Sonnhammer EL. Predicting transmembrane protein topology with a hidden Markov model: application to complete genomes. J Mol Biol. 2001;305(3):567-80. doi:10.1006/ jmbi.2000.4315. Epub 2001/01/12. PubMed.

37. Aziz RK, Bartels D, Best AA, DeJongh M, Disz T, Edwards RA, et al. The RAST Server: rapid annotations using subsystems technology. BMC Genomics. 2008:9:75. doi:10.1186/1471-2164-9-75. Epub 2008/02/12. PubMed PMID: 18261238; PubMed Central PMCID: PMCPmc2265698. 
38. Overbeek R, Begley T, Butler RM, Choudhuri JV, Chuang HY, Cohoon M, et al. The subsystems approach to genome annotation and its use in the project to annotate 1000 genomes. Nucleic Acids Res. 2005;33(17):5691-702. doi:10.1093/nar/gki866. Epub 2005/10/11. PubMed PMID: 16214803; PubMed Central PMCID: PMCPmc1251668.

39. Markowitz VM, Chen IM, Palaniappan K, Chu K, Szeto E, Pillay M, et al. IMG 4 version of the integrated microbial genomes comparative analysis system. Nucleic Acids Res. 2014:42(Database issue):D560-7. doi:10.1093/nar/gkt963. Epub 2013/10/30. PubMed PMID: 24165883; PubMed Central PMCID: PMCPmc3965111.

40. Shulami S, Gat O, Sonenshein AL, Shoham Y. The glucuronic acid utilization gene cluster from Bacillus stearothermophilus T-6. J Bacteriol. 1999:181(12):3695-704. Epub 1999/06/15. PubMed PMID: 10368143; PubMed Central PMCID: PMC93846.

41. Shulami S, Raz-Pasteur A, Tabachnikov O, Gilead-Gropper S, Shner I, Shoham Y. The L-Arabinan utilization system of Geobacillus stearothermophilus. J Bacteriol. 2011;193(11):2838-50. doi:10.1128/JB.00222-11. Epub 2011/04/05. PubMed PMID: 21460081; PubMed Central PMCID: PMC3133107.

42. Zhou Y, Liang Y, Lynch KH, Dennis JJ, Wishart DS. PHAST: a fast phage search tool. Nucleic Acids Res. 2011;39(Web Server issue):W347-52. doi:10.1093/nar/gkr485. PubMed PMID: 21672955; PubMed Central PMCID: PMC3125810.

43. Suzuki Y, Kishigami T, Inoue K, Mizoguchi Y, Eto N, Takagi M, et al. Bacillus thermoglucosidasius sp. nov., a new species of obligately thermophilic Bacilli. Syst Appl Microbiol. 1983;4(4):487-95. doi:10.1016/s0723-2020(83)80006-X. Epub 1983/01/01. PubMed.

44. Hugenholtz P, Pitulle C, Hershberger KL, Pace NR. Novel division level bacterial diversity in a Yellowstone hot spring. J Bacteriol. 1998;180(2):366-76. Epub 1998/01/24. PubMed PMID: 9440526; PubMed Central PMCID: PMCPmc106892.

45. Vishnivetskaya TA, Hamilton-Brehm SD, Podar M, Mosher JJ, Palumbo AV, Phelps $\mathrm{TJ}$, et al. Community analysis of plant biomass-degrading microorganisms from Obsidian Pool. Yellowstone National Park. Microb Ecol. 2015;69(2):333-45. doi:10.1007/s00248-014-0500-8. Epub 2014/10/17. PubMed.

46. Schoenfeld T, Patterson M, Richardson PM, Wommack KE, Young M, Mead D. Assembly of viral metagenomes from yellowstone hot springs. Appl Environ Microbiol. 2008;74(13):4164-74. doi:10.1128/AEM.02598-07. PubMed PMID: 18441115; PubMed Central PMCID: PMC2446518.

47. Pride DT, Schoenfeld T. Genome signature analysis of thermal virus metagenomes reveals Archaea and thermophilic signatures. BMC Genomics. 2008;9:420. doi:10.1186/1471-2164-9-420. PubMed PMID: 18798991; PubMed Central PMCID: PMC2556352.

48. Field D, Garrity G, Gray T, Morrison N, Selengut J, Sterk P, et al. The minimum information about a genome sequence (MIGS) specification. Nat Biotechnol. 2008;26(5):541-7. doi:10.1038/nbt1360. Epub 2008/05/10. PubMed PMID: 18464787; PubMed Central PMCID: PMCPmc2409278.

49. Woese CR, Kandler O, Wheelis ML. Towards a natural system of organisms: proposal for the domains Archaea, Bacteria, and Eucarya. Proc Natl Acad Sci U S A. 1990;87(12):4576-9. PubMed PMID: 2112744; PubMed Central PMCID: PMC54159.

50. Costa KC, Navarro JB, Shock EL, Zhang CL, Soukup D, Hedlund BP Microbiology and geochemistry of great boiling and mud hot springs in the United States Great Basin. Extremophiles. 2009;13(3):447-59. doi:10.1007/ s00792-009-0230-x. PubMed. Epub 2009/02/28.

51. Ashburner M, Ball CA, Blake JA, Botstein D, Butler H, Cherry JM, et al. Gene ontology: tool for the unification of biology. The Gene Ontology Consortium. Nat Genet. 2000;25(1):25-9. doi:10.1038/75556. Epub 2000/05/ 10. PubMed.

\section{Submit your next manuscript to BioMed Central and take full advantage of:}

- Convenient online submission

- Thorough peer review

- No space constraints or color figure charges

- Immediate publication on acceptance

- Inclusion in PubMed, CAS, Scopus and Google Scholar

- Research which is freely available for redistribution 